\title{
Peningkatan Aktivitas dan Hasil Belajar Matematika Siswa SD Melalui Model Realistic Mathematic Education (RME) Pada Siswa Kelas IV Semester I Di SD Negeri 4 Kradenan Kecamatan Kradenan Kabupaten Grobogan Tahun Pelajaran 2017/2018
}

\author{
Endang Susilowati \\ SD Negeri 4 Kradenan \\ UPTD Pendidikan Kecamatan Kradenan \\ Kabupaten Grobogan \\ endangsusilowati652@gmail.com
}

\begin{abstract}
Abstrak
Tujuan penelitian adalah untuk meningkatkan aktivitas siswa dan hasil belajar matematika siswa dengan menerapkan model pembelajaran Realistic Mathematic Education (RME). Jenis metode penelitian adalah Penelitian Tindakan Kelas (PTK) yang dilaksanakan dalam 2 siklus dengan tahapan setiap siklus yaitu perencanaan, pelaksanaan, pengamatan, dan refleksi. Subjek penelitian tindakan kelas ini adalah guru dan siswa kelas IV SD Negeri 4 Kradenan dengan jumlah siswa 27 orang yang terdiri dari 11 orang siswa lakilaki dan 16 orang siswa perempuan.. Teknik pengumpulan data berupa teknik non tes dan teknik tes. Alat pengumpul data menggunakan lembar observasi dan tes formatif. Teknik analisis data menggunakan teknik analisis kualitatif dan analisis kuantitatif. Hasil penelitian menunjukkan bahwa penerapan model pembelajaran Realistic Mathematic Education (RME) dapat meningkatkan aktivitas dan hasil belajar matematika siswa. Hal ini dapat di lihat dari aktivitas siswa pada siklus I memperoleh nilai rata-rata sebesar 59,84 dengan kategori cukup aktif meningkat pada siklus II sebesar 7,78 menjadi 67,62 dengan kategori aktif. Persentase aktivitas siswa secara klasikal pada siklus I sebesar $57,14 \%$ dengan kategori cukup aktif meningkat $19,05 \%$ pada siklus II menjadi $76,19 \%$ dengan kategori aktif. Hasil belajar siswa pada siklus I memperoleh nilai rata-rata 63,81 dengan kategori belum tuntas, meningkat sebesar 10,24 pada siklus II menjadi 74,05 dengan kategori tuntas. Persentase ketuntasan hasil belajar siswa pada siklus I sebesar $61,90 \%$ dengan kategori cukup tinggi, meningkat $14,29 \%$ pada siklus II menjadi 76,19\% dengan kategori tinggi.
\end{abstract}

Kata Kunci : Realistic Mathematic Education (RME), aktivitas siswa, hasil belajar.

\section{PENDAHULUAN}

Sebagai institusi resmi dalam bidang pendidikan, sekolah memiliki peran yang sangat krusial dalam pembentukan dan pengembangan potensi peserta didik. Melalui sistem pendidikan yang diterapkan di sekolah, pengembangan potensi dan pembentukan perilaku individu diharapkan mampu mencapai perkembangan yang optimal.
Pendidikan menjadi tumpuan harapan bagi peningkatan kualitas sumber daya manusia Indonesia seutuhnya. Pendidikan yang mampu mendukung pembangunan dimasa mendatang adalah pendidikan yang mampu mengembangkan potensi siswa, sehingga yang bersangkutan mampu menghadapi dan memecahkan problema kehidupan yang dihadapinya (Trianto, 2011: 1). Undang-undang No. 20 Tahun 2003 tentang Sistem Pendidikan 
Nasional pasal (3) menyebutkan bahwa pendidikan nasional bertujuan untuk berkembangnya potensi peserta didik agar menjadi Manusia yang beriman dan bertakwa kepada Tuhan Yang Maha Esa, berakhlak mulia, sehat, berilmu, cakap, kreatif, mandiri, dan menjadi warga negara yang demokratis serta bertanggung jawab. (Trianto, 2011: 5) menyatakan bahwa masalah utama dalam pembelajaran pada pendidikan formal (sekolah) dewasa ini adalah masih rendahnya daya serap siswa, terlihat dari rerata hasil belajar siswa yang masih sangat memprihatinkan. Kondisi hasil belajar siswa tersebut disebabkan oleh pembelajaran yang masih bersifat konvensional atau masih didominasi oleh guru dan belum melibatkan siswa secara langsung untuk berkembang secara mandiri.

Guru adalah seorang pendidik, pembimbing, pelatih, dan pengembang kurikulum yang dapat menciptakan kondisi dan suasana belajar yang kondusif, yaitu suasana belajar menyenangkan, menarik, memberi rasa aman, memberikan ruang pada siswa untuk berpikir aktif, kreatif, dan inovatif dalam mengeksplorasikan dan mengelaborasi kemampuannya (Rusman, 2011: 19). Guru hendaknya mampu memilih model, pendekatan, strategi, metode dan teknik pembelajaran yang bervariasi sesuai dengan tujuan pembelajaran di sekolah dasar, agar proses pembelajaran menjadi menyenangkan dan siswa dapat mengikuti pembelajaran dengan baik tanpa ada rasa takut. Salah satu mata pelajaran yang ditakuti oleh siswa di sekolah dasar adalah Matematika.

Masalah pendidikan matematika selalu menjadi sorotan, karena masih rendahnya prestasi belajar siswa pada bidang studi tersebut. Usaha untuk meningkatkan mutu pendidikan matematika di Indonesia telah lama dilaksanakan, namun keluhan tentang kesulitan belajar matematika masih saja terus dijumpai.

Rendahnya hasil belajar siswa dalam pembelajaran matematika bukan sematamata karena materi yang sulit, tetapi bisa juga disebabkan oleh proses pembelajaran yang dilaksanakan. Betapapun tepat dan baiknya bahan ajar matematika yang diberikan belumlah menjamin akan tercapainya tujuan pendidikan matematika yang diinginkan. Salah satu faktor penting untuk mencapai tujuan pendidikan adalah proses belajar yang dilaksanakan (Sutawidjaja \& Afgani, 2015). Kenyataan di lapangan menunjukkan bahwa pembelajaran matematika pada umumnya masih terpusat pada guru, bukan pada siswa.

Matematika merupakan salah satu bidang studi yang ada pada semua jenjang pendidikan. Menurut Susanto (2013: 183) belajar matematika merupakan suatu syarat cukup untuk melanjutkan pendidikan ke jenjang selanjutnya. (Hamzah, 2014: 57) menyatakan bahwa pendidikan matematika merupakan upaya untuk meningkatkan daya nalar siswa, meningkatkan kecerdasan siswa, dan mengubah sikap positifnya. Mengingat pentingnya matematika dalam kehidupan sehari-hari dan dalam perkembangan IPTEK, sekolah sebagai lembaga pendidikan formal hendaknya mampu melaksanakan proses pembelajaran matematika yang bermakna dan menarik sehingga konsep matematika yang terkesan sulit dan abstrak dapat dimengerti dengan mudah oleh siswa.

Pada pengajaran matematika guru cenderung mentransfer pengetahuan yang mereka miliki ke dalam pikiran siswa. Siswa sering diposisikan sebagai orang yang "tidak tahu apa-apa" yang hanya menunggu apa yang guru berikan (Ratumanan, 2003). Dalam kurikulum matematika sekolah di Indonesia dan dalam pembelajarannya selama ini terpateri kebiasaan dengan urutan 
sajian pembelajaran sebagai berikut: (1) diajarkan teori/ teorema/ definisi (2) diberikan contoh-contoh dan (3) diberikan latihan soal-soal. Kebiasaan pembelajaran semacam ini menyebabkan guru mendominasi kegiatan belajar mengajar, sementara siswa hanya menjadi pendengar dan pencatat yang baik. Hasilnya adalah siswa yang kurang mandiri, tidak berani mengemukakan pendapat sendiri, selalu meminta bimbingan guru, dan kurang gigih melakukan ujicoba dalam menyelesaikan masalah matematika, sehingga pengetahuan yang dipahami siswa hanya sebatas apa yang diberikan guru. Dalam proses pembelajaran guru hendaknya memberikan arahan kepada siswa tentang bagaimana siswa harus belajar. Seperti yang diungkapkan oleh (Arends, 2014) bahwa good teaching includes teaching students how to learn, how to remember, how to think, and how to motivate themselves.

Peran guru dalam kegiatan belajar mengajar adalah sebagai fasilitator dan motivator untuk mengoptimalkan belajar siswa. (Ratumanan, 2003) menyarankan agar guru berpandangan bahwa matematika merupakan proses, sehingga pengajaran matematika merupakan suatu usaha membantu siswa untuk mengkonstruksi pengetahuan dengan kemampuannya sendiri melalui proses internalisasi sehingga pengetahuan tersebut terkonstruksi kembali.

Pada pandangan konstruktivis, mengajar bukanlah meneruskan pengetahuan dari kepala guru ke kepada siswa, tetapi mengajar adalah proses negosiasi makna. (Permana, 2015) Guru lebih banyak berperan sebagai fasilitator dan mediator yang kreatif, sedangkan siswa dipandang sebagai bagian yang aktif dan bertanggung jawab atas pembelajarannya sendiri. Salah satu ciri lingkungan belajar yang beraliran konstruktivis adalah jika dalam mengajar guru mengintegrasikan pembelajaran dengan situasi yang realistis dan relevan serta melibatkan siswa baik secara emosional maupun sosial agar pembelajaran matematika menjadi menarik dan menyenangkan (Permana, 2016). Selanjutnya (Burril, 1997) mengemukakan bahwa Good teaching is not making learning easy!, is not making hard either. Students, teachers, parents, and administrators should understand that good teaching means that students are actively engaged in the learning process. Students are involved with problems, they struggle with ideas, and they take part in the dialogue.

Model pembelajaran Realistic Mathematics Education (RME) merupakan salah satu alternatif pembelajaran yang menuntut siswa untuk mengkonstruksi pengetahuan dengan kemampuannya sendiri melalui aktivitas yang dilakukannya dalam kegiatan pembelajaran. Ide utama pembelajaran dengan menggunakan model pembelajaran RME adalah siswa harus diberi kesempatan untuk menemukan kembali (reinventing) konsep matematika dengan bimbingan orang dewasa (Gravemeijer, 1994). Prinsip menemukan kembali berarti siswa diberi kesempatan menemukan sendiri konsep matematika dengan menyelesaikan berbagai soal kontekstual yang diberikan pada awal pembelajaran.

Berdasarkan pada soal, siswa membangun model berdasarkan situasi kemudian menyelesaikan hingga mendapatkan pengetahuan formal matematika (Gravemeijer, 1994). Selain itu dalam pandangan ini, matematika dipandang sebagai suatu kegiatan manusia sehari-hari. Oleh karena itu pembelajaran matematika harus dikaitkan dan menjadi bagian dari kegiatan manusia sehari-hari (Gravemeijer, 1994). 
Upaya untuk menemukan kembali ide dan konsep matematika ini dilakukan dengan memanfaatkan realita dan lingkungan yang dekat dengan anak. Pembelajaran matematika realistik pada dasarnya adalah pemanfaatan realita dan lingkungan yang dipahami peserta didik untuk memperlancar proses pembelajaran matematika sehingga mencapai tujuan pendidikan matematika secara lebih baik daripada masa yang lalu. Lebih lanjut yang dimaksud dengan realita yaitu hal-hal yang nyata atau konkrit yang dapat diamati atau dipahami peserta didik lewat membayangkan, sedangkan yang dimaksud dengan lingkungan adalah lingkungan tempat peserta didik berada baik lingkungan sekolah, keluarga maupun masyarakat yang dapat dipahami peserta didik (Putri, 2013).

Model Pembelajaran RME telah dikembangkan di Belanda selama kurang lebih 30 tahun, dan menunjukkan hasil yang baik. RME juga dikembangkan di beberapa negara lain seperti USA (yang dikenal dengan Mathematics in Context), Afrika Selatan, Malaysia, Inggris, Brazil, dan lainlain. Laporan dari TIMMS (Third International Mathematics and Science Study) menyebutkan bahwa berdasarkan penilaian TIMSS, siswa di Belanda memperoleh hasil yang memuaskan baik dalam ketrampilan komputasi maupun kemampuan pemecahan masalah.

Belajar matematika merupakan kegiatan mental yang tinggi karena matematika berkenaan dengan ide-ide abstrak yang diberi simbol-simbol yang tersusun secara hirarkis dan penalarannya deduktif. Belajar matematika pada hakikatnya adalah belajar berkenaan dengan ide-ide, struktur-struktur yang diatur menurut urutan yang logis.

Proses pembelajaran matematika dengan RME menggunakan masalah kontekstual (contextual problems) sebagai titik awal dalam belajar matematika. Dalam hal ini siswa melakukan aktivitas matematisasi horisontal, yaitu siswa mengorganisasikan masalah dan mencoba mengidentifikasi aspek matematika yang ada pada masalah tersebut. Siswa bebas mendeskripsikan, menginterpretasikan dan menyelesaikan masalah kontekstual dengan caranya sendiri berdasarkan pengetahuan awal yang dimiliki. Kemudian siswa dengan bantuan atau tanpa bantuan guru, menggunakan matematisasi vertikal (melalui abstraksi maupun formalisasi) tiba pada tahap pembentukan konsep. Setelah dicapai pembentukan konsep, siswa dapat mengaplikasikan konsep-konsep matematika tersebut kembali pada masalah kontekstual, sehingga memperkuat pemahaman konsep.

(Gravemeijer, 1994) mengemukakan bahwa terdapat tiga prinsip kunci dalam model pembelajaran RME yaitu (a) Petunjuk menemukan kembali/ matematisasi progresif (guided reinvention / progessive mathematizing), (b) Fenomena yang bersifat mendidik (didactical phenomenology), (c) Mengembangkan model sendiri (Self developed models). Dalam menyelesaikan masalah kontekstual, siswa diberi kesempatan untuk mengembangkan model mereka sendiri, sehingga dimungkinkan muncul berbagai model buatan siswa. Model-model tersebut diharapkan akan berubah dan mengarah kepada bentuk yang lebih baik menuju ke arah pengetahuan matematika formal, sehingga diharapkan terjadi urutan pembelajaran seperti berikut "masalah kontekstual" -"model dari masalah kontekstual tersebut" - "model ke arah formal" - "pengetahuan formal" (Soedjadi, 2007).

Berdasarkan prinsip dan karakteristik model pembelajaran RME maka yang menjadi ciri-ciri dari model pembelajaran ini adalah sebagai berikut. 1) Pembelajaran dirancang berawal dari pemecahan masalah 
yang ada di sekitar siswa dan berbasis pada pengalaman yang telah dimiliki siswa. 2) Urutan pembelajaran haruslah menghadirkan suatu aktivitas atau eksplorasi. 3) Pembelajaran matematika tidak semata-mata memberi penekanan pada komputasi dan hanya mementingkan langkah-langkah prosedural serta keterampilan, melainkan penekanan pada pemahaman konsep dan pemecahan masalah. 4) Siswa mengalami proses pembelajaran secara bermakna dan memahami matematika dengan penalaran. 5) Siswa belajar matematika dengan pemahaman secara aktif membangun pengetahuan baru dari pengalaman dan pengetahuan awal. 6) Dalam pembelajaran siswa dilatih untuk megikuti pola kerja, intuisi - coba - salah - dugaan/ spekulasi hasil. 7) Terdapat interaksi yang kuat antara siswa yang satu dengan siswa lainnya. 8) Memberikan perhatian yang seimbang antara matematisasi horizontal dan matematisasi vertikal.

Secara umum tujuan penelitian adalah untuk mengetahui efektifitas penerapan model pembelajaran RME dalam pembelajaran matematika. Secara khusus tujuan penelitian ini adalah untuk mendeskripsikan: (a) Kemampuan guru dalam mengelola pembelajaran RME, (b) Respon siswa terhadap model pembelajaran RME, (c) pencapaian ketuntasan belajar siswa yang belajar dengan RME.

Melalui penelitian ini, diharapkan bahwa informasi efektivitas pembelajaran matematika dengan menggunakan model pembelajaran RME dapat dijadikan sebagai suatu alternatif pembelajaran matematika, dalam rangka meningkatkan mutu pendidikan matematika melalui peningkatan aktivitas siswa dan minat siswa dalam belajar.

Hasil dari wawancara, observasi, dan dokumentasi di SD Negeri 4 Kradenan menunjukkan bahwa dalam proses pembelajaran matematika di kelas IV siswa cenderung pasif karena kurang dilibatkan dalam mencari penyelesaian masalah matematika. Pembelajaran menjadi kurang bermakna karena pengetahuan yang diperoleh siswa hanya sebatas pada materi yang disampaikan oleh guru. Kegiatan pembelajaran memfokuskan siswa untuk menghafal rumus daripada menanamkan konsep. Kurangnya penggunaan media atau alat peraga dalam pembelajaran matematika.

Selain itu, belum diterapkannya model pembelajaran Realistic Mathematic Education (RME) pada pembelajaran matematika secara optimal. Akibatnya, hasil belajar siswa menjadi rendah. Dari jumlah 27 orang siswa, terdapat 10 orang siswa yang tuntas $(37,03 \%)$ dan terdapat 17 orang siswa belum tuntas $(62,97 \%)$ dengan KKM 66. Proses pembelajaran yang diharapkan adalah memberikan kesempatan kepada siswa untuk berpartisipasi secara aktif dan mampu meningkatkan pemahaman siswa sehingga pembelajaran menjadi lebih bermakna.

Berkaitan dengan uraian di atas, peneliti menerapkan model pembelajaran Realistic Mathematic Education (RME). Menurut (Muhsetyo, 2008). Freudenthal dan Treffers adalah tokoh-tokoh yang mengembangkan RME, pada awalnya diterapkan di Belanda dan digunakan sebagai model untuk meningkatkan mutu pembelajaran matematika. (Aisyah, 2007) menyatakan bahwa Realistic Mathematic Education (RME) adalah salah satu model pembelajaran matematika yang dikembangkan untuk mendekatkan matematika kepada siswa.

Langkah-langkah penerapan model pembelajaran Realistic Mathematic Education (RME) yang dikemukakan oleh (Wijaya, 2017) yaitu: (1) diawali dengan masalah dunia nyata, (2) mengidentifikasi 
konsep matematika yang relevan dengan masalah, lalu mengorganisir masalah sesuai dengan konsep matematika, (3) secara bertahap meninggalkan situasi dunia nyata melalui proses perumusan asumsi, generalisasi, dan formalisasi, (4) menyelesaikan masalah matematika (terjadi dalam dunia matematika), dan (5) menerjemahkan kembali solusi matematis ke dalam solusi nyata, termasuk mengidentifikasi keterbatasan dari solusi. Menurut (Wijaya, 2017: 20-21) model pembelajaran Realistic Mathematic Education (RME) memiliki kelebihan dan kelemahan, kelebihan model pembelajaran Realistic Mathematic Education (RME) yaitu: (1) memberikan pengertian kepada siswa tentang keterkaitan matematika dengan kehidupan sehari-hari, dan (2) memberikan pengertian kepada siswa bahwa matematika adalah suatu bidang kajian yang dikonstruksi dan dikembangkan sendiri oleh siswa tidak hanya oleh mereka yang disebut pakar dalam bidang tersebut, sedangkan kelemahan model pembelajaran Realistic Mathematic Education (RME) yaitu: (1) tidak mudah bagi guru untuk mendorong siswa agar bisa menemukan berbagai cara dalam menyelesaikan soal atau memecahkan masalah, dan (2) tidak mudah bagi guru untuk memberi bantuan kepada siswa agar dapat melakukan penemuan kembali konsep-konsep matematika yang dipelajari.

Proses pembelajaran melalui penerapan model pembelajaran Realistic Mathematic Education (RME) diharapkan mampu meningkatkan kualitas belajar yang juga dipengaruhi oleh kinerja guru. Menurut (Susanto, 2013) kinerja guru dapat diartikan sebagai prestasi, hasil, atau kemampuan yang dicapai atau diperlihatkan oleh guru dalam melaksanakan tugas pendidikan dan pengajaran. Pembelajaran akan berhasil dan dikatakan efektif apabila siswa ikut terlibat dan berpartisipasi aktif dalam kegiatan belajar. Proses aktivitas pembelajaran harus melibatkan seluruh aspek psikofisis siswa, baik jasmani maupun rohani sehingga akselerasi perubahan perilakunya dapat terjadi secara cepat, tepat, mudah, dan benar, baik berkaitan dengan aspek kognitif, afektif, maupun psikomotor (Hanafiah \& Suhana, 2012) Hasil belajar adalah kompetensi atau kemampuan tertentu baik kognitif, afektif maupun psikomotorik yang dicapai atau dikuasai siswa setelah mengikuti proses belajar mengajar (Kunandar, 2011). Berdasarkan uraian di atas, peneliti melakukan penelitian tindakan kelas dengan judul "Penerapan Model Pembelajaran Realistic Mathematic Education (RME) untuk Meningkatkan Aktivitas dan Hasil Belajar Matematika Siswa Kelas IV SD Negeri 4 Kradenan". Tujuan penelitian ini adalah untuk meningkatkan aktivitas siswa dan hasil belajar siswa pada mata pelajaran matematika kelas IV SD Negeri 4 Kradenan melalui penerapan model pembelajaran Realistic Mathematic Education (RME).

\section{METODE PENELITIAN}

Penelitian ini menggunakan jenis metode Penelitian Tindakan Kelas (PTK) atau dikenal dengan Classroom Action Research, dan dilaksanakan dalam 2 siklus. Tahapan setiap siklus yaitu: perencanaan, (2) pelaksanaan, pengamatan, dan (4) refleksi (Arikunto, 2013). Penelitian tindakan kelas ini dilaksanakan secara kolaboratif partisipatif antara peneliti dengan guru wali kelas IV dan dilaksanakan pada semester genap tahun pelajaran 2017/2018. Subjek penelitian tindakan kelas ini adalah guru dan siswa kelas IV SD Negeri 4 Kradenan dengan jumlah siswa 27 orang yang terdiri dari 11 orang siswa laki-laki dan 16 orang siswa perempuan. Teknik pengumpulan data menggunakan teknik non tes dan teknik tes. 
Alat Pengumpul data menggunakan lembar observasi dan tes formatif. Lembar observasi digunakan untuk mengamati kinerja guru, dan aktivitas siswa, sedangkan tes formatif digunakan untuk mengetahui hasil belajar kognitif siswa. Data yang diperoleh dianalisis menggunakan teknik analisis kualitatif dan analisis kuantitatif (Permana \& Imron, 2016).

Pengumpulan data penelitian ini menggunakan teknik analisis dokumen, pengamatan pada pelaksanaan pembelajaran, dan wawancara mendalam terhadap informan. Teknik cuplikan (sampling) yang digunakan adalah purposive (purposive sampling) dan snawball sampling. Uji validitas data yang dilakukan penulis pada penelitian ini adalah dengan triangulasi metode, triangulasi sumber, dan review informan. Teknik analisis data yang digunakan adalah analisis model interaktif (interactive model of analysis) yang dikembangkan (Miles \& Huberman, 2002).

\section{HASIL DAN PEMBAHASAN}

Penelitian ini menggunakan metode penelitian tindakan kelas (PTK) yang berkolaboratif (collaborative classroom action research) (Barker, Reynolds, \& Place, 2005). Meski demikian metode ini ditekankan dengan guru sebagai peneliti (teacher as researcher) (Permana, 2011). Model ini relevan bagi guru dan dosen dan memiliki keunggulan, sebab efektif dapat memperbaiki kualitas pembelajaran yang dilakukannya. Pelaksanaan penelitian ini terdiri atas tiga langkah yaitu (1) diagnostik (perumusan masalah dan hipotesis tindakan), (2) terapetik (perbaikan yang terdiri atas beberapa siklus: perencanaan pelaksanaan - pengamatan - refleksi) dan (3) pasca terapetik (pemantapan dan pembuatan laporan) (Barker et al., 2005).

Penelitian ini dilaksanakan di kelas IV SD Negeri 4 Kradenan Kecamatan
Kradenan Kabupaten Grobogan pada semester satu tahun pelajaran 2017/2018. Terdapat dua siklus dalam penelitian ini, setiap siklus terdiri dari dua pertemuan. Penelitian siklus I dilaksanakan pada hari Kamis tanggal 20 Juli 2017 pukul 07.3008.40 WIB dan hari Sabtu tanggal 22 Juli 2017 pukul 08.05-09.15 WIB. Siklus II dilaksanakan pada hari Kamis tanggal 3 Agustus 2017 pukul 07.30-08.40 WIB dan hari Sabtu tanggal 5 Agustus 2017 pukul 08.05-09.15 WIB.

Hasil penelitian menunjukkan terdapat peningkatan terhadap kinerja guru, aktivitas siswa dan hasil belajar kognitif siswa dari siklus I ke siklus II sebagai berikut.

Tabel 1. Peningkatan kinerja guru.

\begin{tabular}{ccccc}
\hline No & Keterangan & Siklus I Siklus II & Peningkatan \\
\hline 1 & Nilai & 64,17 & 80,17 & 16,00 \\
& & \multicolumn{3}{c}{$\begin{array}{c}\text { Sangat } \\
\text { baik }\end{array}$} \\
2 & Kategori & Baik & baik \\
\hline
\end{tabular}

Berdasarkan tabel 1 diperoleh informasi bahwa nilai kinerja guru siklus I sebesar 64,17 dengan kategori baik, mengalami peningkatan pada siklus II sebesar 16,00 menjadi 80,17 dengan kategori sangat baik. Wujud perilaku yang berkaitan dengan kinerja guru adalah kegiatan guru dalam proses pembelajaran, yaitu bagaimana seorang guru merencanakan pembelajaran dan menilai hasil belajar (Rusman, 2011).

Tabel 2. Peningkatan aktivitas siswa.

\begin{tabular}{ccccc}
\hline No & Keterangan & Siklus I Siklus II & Peningkatan \\
\hline 1 & Nilai rata-rata & 59,84 & 67,62 & 7,78 \\
2 & Kategori & Cukup & Aktif & \\
& Persentase & & & \\
3 & aktivitas & $57,14 \%$ & $76,19 \%$ & $19,05 \%$ \\
& siswa & & & \\
4 & Kategori & Cukup & Aktif & \\
\hline
\end{tabular}


Berdasarkan tabel 2 dapat diketahui bahwa nilai rata-rata aktivitas siswa pada siklus I sebesar 59,84 dengan kategori cukup aktif, meningkat 7,78 pada siklus II menjadi 67,62 dengan kategori aktif. Persentase aktivitas siswa pada siklus I sebesar 57,14\% dengan kategori cukup aktif, meningkat $19,05 \%$ pada siklus II menjadi 76,19\% dengan kategori aktif. Aktivitas tersebut merupakan keterlibatan siswa dalam bentuk sikap, pikiran, perbuatan, dan aktivitas dalam kegiatan pembelajaran guna menunjang keberhasilan proses belajar mengajar dan memperoleh manfaat dari kegiatan belajar (Kunandar, 2011).

Tabel 3. Peningkatan hasil belajar siswa.

\begin{tabular}{ccccc}
\hline No & Keterangan & Siklus I & Siklus II & Peningkatan \\
\hline 1 & Nilai rata-rata & 63,81 & 74,05 & 10,24 \\
2 & Kategori & $\begin{array}{c}\text { Belum } \\
\text { Tuntas }\end{array}$ & Tuntas & \\
& Persentase & $61,90 \%$ & $76,19 \%$ & $14,29 \%$ \\
3 & ketuntasan & Cukup & Tinggi & \\
4 & Kategori & Tinggi & & \\
\hline
\end{tabular}

Berdasarkan tabel 3 dapat diketahui bahwa nilai rata-rata hasil belajar siswa pada siklus I sebesar 63,81 dengan kategori belum tuntas meningkat sebesar 10,24 pada siklus II menjadi 74,05 dengan kategori tuntas. Persentase ketuntasan hasil belajar siswa pada siklus I adalah $61,90 \%$ dengan kategori cukup tinggi, meningkat sebesar $14,29 \%$ pada siklus II menjadi $76,19 \%$ dengan kategori tinggi. Hasil analisis tersebut sesuai dengan pendapat (Muhsetyo, 2008) yang menyatakan bahwa model pembelajaran Realistic Mathematic Education (RME) adalah model pembelajaran yang dapat digunakan untuk meningkatkan mutu pembelajaran matematika.

\section{SIMPULAN}

Berdasarkan analisis data dapat diperoleh kesimpulan bahwa penerapan model pembelajaran Realistic Mathematic Education (RME) dapat meningkatkan aktivitas siswa dan hasil belajar siswa pada mata pelajaran matematika pada siswa kelas IV semester I SD Negeri 4 Kradenan Kecamatan Kradenan tahun pelajaran 2017/2018. Aktivitas siswa pada siklus I memperoleh nilai rata-rata sebesar 59,84 dengan kategori cukup aktif meningkat pada siklus II sebesar 7,78 menjadi 67,62 dengan kategori aktif. Persentase aktivitas siswa secara klasikal pada siklus I sebesar 57,14\% dengan kategori cukup aktif meningkat $19,05 \%$ pada siklus II menjadi 76,19\% dengan kategori aktif. Hasil belajar siswa pada siklus I memperoleh nilai rata-rata 63,81 dengan kategori belum tuntas, meningkat sebesar 10,24 pada siklus II menjadi 74,05 dengan kategori tuntas. Persentase ketuntasan hasil belajar siswa pada siklus I sebesar $61,90 \%$ dengan kategori cukup tinggi, meningkat 14,29\% pada siklus II menjadi $76,19 \%$ dengan kategori tinggi.

Dari hasil penelitian deskriptif tentang pembelajaran matematika dengan metode RME dapat disimpulkan hal-hal sebagai berikut. 1). Guru yang diteliti ternyata telah memiliki kemampuan yang cukup untuk melakukan pembelajaran matematika dengan metode RME. Guru juga telah dapat melaksanakan pembelajaran tersebut secara efektif. 2) Respons siswa terhadap pembelajaran matematika RME adalah positif. Sebagian besar siswa senang dengan metode tersebut, dan sebagian besar pula menganggap sebagai hal yang baru. 3) Berkaitan dengan ketuntasan belajar, walaupun terjadi peningkatan hasil belajar, namun menurut standar yang berlaku ketuntasan belajar siswa belum tercapai. 
Secara umum, penelitian yang lebih mendalam masih perlu untuk dilakukan guna mencari tahu faktor-faktor lain yang mempengaruhi dan menyebabkan ketidaktuntasan belajar tersebut. Selain itu perlu pula dilakukan perbandingan hasil belajar dengan RME dan dengan metode ekspositori biasa. Dengan demikian informasi yang lebih mendalam dapat diketahui dalam upaya meningkatkan kualitas pembelajaran matematika di dalam kelas secara umum

\section{DAFTAR RUJUKAN}

Aisyah, N. (2007). Pengembangan

Pembelajaran Matematika SD. Jakarta:

Dirjen Dikti Depdiknas.

Arends, R. (2014). Learning to Teach. In Handbook of educational psychology (p. 608).

https://doi.org/10.1017/CBO978110741 5324.004

Arikunto. (2013). Metodelogi Penelitian, Suatu Pengantar Pendidikan. Rineka Cipta, Jakarta.

Barker, R., Reynolds, J., \& Place, M. (2005). Action research, self esteem, and children and young people in need with "medium range" behavioural difficulties. Journal of Social Work Practice, 19(3), 299-315. https://doi.org/10.1080/0265053050029 1278

Burril, G. (1997). President's report: Choice and challenges. Journal for Research in Mathematics Education, 28(3).

Gravemeijer, K. (1994). Educational Development and Developmental Research in Mathematics Education. Journal for Research in Mathematics Education, 25(5), 443-471. https://doi.org/10.2307/40539302

Hamzah, A. (2014). Perencanaan dan Strategi Pembelajaran Matematika. Jakarta: Rajawali Pers.

Hanafiah, N., \& Suhana, C. (2012). Konsep Strategi Pembelajaran. Konsep pembelajaran.

Kunandar. (2011). Langkah Mudah Penelitian Tindakan Kelas sebagai
Pengembangan Profesi Guru. Jakarta: Rajawali Pers.

Miles, M. B., \& Huberman, A. M. (2002). Reflections and Advice. In The Qualitative Researchers Companion (pp. 393-398). https://doi.org/10.4135/9781412986274

Muhsetyo, G. (2008). Pembelajaran Matematika SD. Jakarta: Universitas Terbuka.

Permana, E. P. (2011). Meningkatkan hasil belajar melalui metode problem solving dalam pembelajaran IPS di kelas IV SDN Kotes 01 Kecamatan Gandusari Kabupaten Blitar. Skripsi (Sarjana)-Universitas Negeri Malang.

Permana, E. P. (2015). PENERAPAN METODE PROBLEM SOLVING DENGAN MEDIA GAMBAR SERI UNTUK MENINGKATKAN HASIL BELAJAR IPS KELAS IV SEKOLAH DASAR. Jurnal Pendidikan Dasar Nusantara, 1(1), 1-16.

Permana, E. P. (2016). PENERAPAN

METODE PEMBELAJARAN KOOPERATIF NUMBERED HEADS TOGETHER (NHT) UNTUK MENINGKATKAN HASIL BELAJAR DAN BERPIKIR KRITIS SISWA PADA MATA PELAJARAN IPS SD. Jurnal Pendidikan Dasar Nusantara, 1(2), 49-58.

Permana, E. P., \& Imron, I. F. (2016). PENERAPAN PEMBELAJARAN IPS DENGAN MEDIA ULAR TANGGA UNTUK MENINGKATKAN MINAT BELAJAR SISWA KELAS IV SDN KECAMATAN PRAMBON NGANJUK. EFEKTOR, 1(28), 67-70.

Putri, finola M. (2013). PENGARUH PEMBELAJARANMATEMATIKA REALISTIK TERHADAP KEMAMPUAN PENALARANMATEMATIS SISWASMP. Edumatica Volume, 3(1), 19-26.

Ratumanan, T. (2003). Pengaruh model pembelajaran dan gaya kognitif terhadap hasil belajar matematika siswa SLTP di Kota Ambon. Jurnal Pendidikan Dasar, 5(1), 1-10. Rusman. (2011). Model-model 
Pembelajaran. Jakarta: Rajawali Pers.

Soedjadi, R. (2007). Inti Dasar-dasar Pendidikan Matematika Realistik Indonesia. Jurnal Penddidikan Matematika, 1(2), 1-10.

Susanto, A. (2013). Teori Belajar dan Pembelajaran di Sekolah Dasar. Jakarta: Kencana.

Sutawidjaja, A., \& Afgani, J. (2015).

Konsep Dasar Pembelajaran

Matematika. Pembelajaran

Matematika, 1-25.

Trianto. (2011). Mendesain Model
Pembelajaran Inovatif-Progresif. Kencana.

Wijaya, D. A. I. dan A. (2017).

PENGEMBANGAN PERANGKAT

PEMBELAJARAN BERBASIS

PENDEKATAN MATEMATIKA

REALISTIK MATERI BANGUN

RUANG SISI DATAR

BERORIENTASI PADA

KEMAMPUAN BERPIKIR KRITIS

SISWA KELAS VIII SMP. Pendidikan

Matematika, 6(5), 24-36. 